\title{
UNIVERSITYOF
}

FORWARD

THINKING

WESTMINSTER用

WestminsterResearch

http://www.westminster.ac.uk/westminsterresearch

Water Governance in Decentralising Indonesia

Rahayu, P., Woltjer, J. and Firman, T.

This is a copy of the accepted author manuscript of the following article: Woltjer, J., Rahayu, P. and Firman, T. (2019) Water Governance in Decentralising Indonesia, Urban Studies, DOI: 10.1177/0042098018810306.

The final definitive version is available from the publisher Sage at:

https://doi.org/10.1177/0042098018810306

(C) The Author(s) 2019

The WestminsterResearch online digital archive at the University of Westminster aims to make the research output of the University available to a wider audience. Copyright and Moral Rights remain with the authors and/or copyright owners.

Whilst further distribution of specific materials from within this archive is forbidden, you may freely distribute the URL of WestminsterResearch: ((http://westminsterresearch.wmin.ac.uk/)).

In case of abuse or copyright appearing without permission e-mail repository@westminster.ac.uk 


\section{Water Governance in Decentralising Indonesia}

\section{Abstract}

Abstract: Under new democratic regimes in the country of the South, governance innovation is often found at the regional level. This article, using the concept of institutional capacity, shows that powerful efforts affecting regional water resource coordination emerge locally.

The paper analyzes fresh water cooperation in the urban region of Cirebon, Indonesia. It is shown that city and their surrounding regions in decentralizing Indonesia show signs of increasing institutional capacity between local actors. An informal approach and discretionary local decision-making, influenced by logic of appropriateness and tolerance are influential. At the same time, these capacities are compromised by significant inequality and a unilateral control of water resources, and they are being challenged by a strong authoritarian political culture inherited from a history of centralized government.

The paper points to the need to establish greater opportunities for water governance at the regional level to transcend inter-local rivalry, and thus improve decentralized institutional capacity further.

\section{Introduction}

Coordination for the provision of water resources has become an increasingly pressing issue for cities worldwide. Water resource availability is particularly challenging in the urban areas of less developed regions, where the urban population is increasingly concentrated, particularly in smaller and medium-sized cities (UN, 2010). It is crucial that these cities with a population of typically less than five hundred thousand have arrangements in place to provide water and thus facilitate urban life.

Water challenges emerging in smaller urban areas are as complex as those facing larger metropolitan regions. In general terms, Cohen (2006) has characterized the position of these areas with the phrase "small cities, big agenda": considerable population numbers, a substantial speed of urban growth, the lack of infrastructure, resources and services, as well as the capacity to respond those challenges. Cohen's argument points fundamentally 
to a lack of local capacity. Linked to, but distinct from, capacity-related problems is a growing concern with the institutional challenges facing smaller cities as a result of decentralization taking place in developing countries. Some scholars claim that the implementation of decentralization policy - particularly in the case of smaller cities in the South - reveals important variations in how they manage the process (Han, 2010; Klaufus, 2010; Liu, et al. 2011). Stakeholders of newly decentralized countries commonly have different frames of reference and conflicting interests as they interpret, understand, and negotiate their new responsibilities, roles, and relationships. In this sense, they often lack the capacity to steer processes of urban development and associated needs in terms of water resources and their infrastructures.

Different from those in the north, where local and regional governments are able to establish collective action to provide services for regional areas (Hawkins, Hu, and Feiock, 2016; Hoornbeek, Beechey, and Pascarella, 2015), major studies on governance in countries of the South generally point out the influence of the institutional legacies of (former) authoritarian regimes. The institutional legacies act as structuring forces for the management of resources in cities and regions. They influence the selected models of governance as well as their formation process. Improvement of the capacity for intergovernmental negotiation involves both formal and informal institutions. Under the new democratic regimes, innovation is often found at the national and sub-national level and in regional governance (see among others Firman, 2010; Gore and Gopakumar, 2014; Guarneros-Meza, 2009; Laquian, 2005; Vogel, et al. 2010).

This article seeks to demonstrate that powerful efforts affecting the formation of regional governance in a decentralizing context emerge from the local level: municipalities 
and districts. The research question asks what factors might explain governance innovation in the context of newly decentralized institutions for water resource management. In so doing, we investigate how innovative practices are represented in the transformation of institutional capacity for dealing with water resources in an Indonesian small to mediumsized urban area. The article shows a dramatic change from a centralized system with the institutional legacies of an authoritarian regime, to dynamic and strong local governance. In Indonesia, substantial authorities have been delegated to local government level thus far without corresponding financial decentralization. At the same time, considerable innovations at the local level occur, both in terms of power and networks as well as financially, to maintain local development processes to run well. Smaller or secondary cities, with substantial limitation of water resources and limited administrative area, are strongly affected by this situation of political decentralization.

Water resources are an essential driver in the management of urban regions. Issues of protection, distribution, and supply are at stake, typically in terms of regional coordination between upstream and downstream areas. Water governance refers to the inclusion of a variety of actors. A defining factor is in the engagement of these actors with the production, usage, and development of specific water resources. Typical governance aspects include the possibilities for stakeholder engagement, the limitations of water supplies, the management of demand, the exercise of legal rights such as access and ownership, and platforms for consultation and decision making (e.g., White, 2010; Megdal, et al, 2017). Local fragmentation also plays an important role as water use and consumption in cities often appear locally, and water systems as a whole are fundamentally regional in 
nature, and are characterized by inequalities in accessibility and use while demand from urban growth adds ever-increasing pressure (e.g., Kim, 2015).

Our case study is concerned with the governance of water resources both locally and at the regional level. Using Cirebon City and its surrounding region, Kuningan District, this article identifies a distinct formation process of institutional capacity for water resources in a decentralized system of governance. Water resource management practice here incorporates issues of local leadership and, essentially, patrimonial control over local territory and its natural resources.

\section{Figure 1. Cirebon City and Kuningan District}

\section{. Methodology}

Cirebon City is a $37 \mathrm{~km}^{2}$ municipal city with about 300 thousand inhabitants, located in the northeastern part of the West Java Province. Compared to Indonesian cities such as Jakarta $\left(661 \mathrm{~km}^{2}\right)$ and Surabaya $\left(350 \mathrm{~km}^{2}\right)$ Cirebon is small in size. The city is the center of several districts, including Kuningan District. Cirebon City is located downstream, and does not have any sufficient water resources for its piped water supply. Kuningan District is located upstream, with abundant natural water resources. The utilization of water between the two regions should be based on coordination and sharing between upstream and downstream areas. The area features a conflict of water-resource 
utilization in the context of rapid urban growth of the areas surrounding Cirebon city (Fahmi et al., 2014).These characteristics exhibit a typical example of a city with limited capacity and resources undergoing the pressures of urbanization, decentralization, and challenging impediments to coordination.. These characteristics make it that Cirebon represents a "force of example" (Flyvberg 2006, p. 228) for issues of water governance in developing countries.

Following a case study approach, multiple data sources were triangulated. The fieldwork involved a combination of secondary and primary data. As for secondary data, policy documents, letters, memos, minutes of meetings, and research reports were collected. These data were arranged to deliver a detailed chronology of water-resource cooperation. As for primary data, participants for in-depth interviews were selected based on purposive and snowball sampling. Following Miles and Huberman (1994) selection was not prespecified completely and evolved during the study. Participants were selected from three different domains: (1) local government officials (Local Water Supply Agency, Planning Agency, Public Works, and Local Secretariat); (2) water-related NGOs (Fahmina Institute, JAMS/Neworking for Community Aspiration); (3) staff of a widely distributed local newspaper (Radar Cirebon).

To the pool of initially selected participants, supplementary prospective participants were identified and interviewed, to gather further information and achieve saturation. These additional participants included the Mayor of Cirebon-previously Head of the Regional Coordination Board of Ciayumajakuning, the Regent of Kuningan, national officials and village leaders of Singkup and Paniis. The total numbers of respondents amounted to 34. Data from the interviews were analyzed using standard coding analysis. 
To support the result, several on-line national and local newspapers were reviewed to validate the investigation. Finally, the analysis included a review of main regulations on water resources including Water Law No 7/2004 and several regulations on inter-local government collaboration and decentralization.

\section{Positioning the institutional capacity concept in the governance literature}

Governance involves an assembly of institutions that overlap and are linked through different processes involving civil society and economic relations (Jessop, 1998). Rescaling the power of the state to the local and civil society is a crucial part of governance (Wu, 2002; McCann, 2016). Territorially, governance should be beyond merely cities’ territory, but covering city- regions (MacLeod 2011). Stakeholders must be able to develop new capacity in accordance to the new assembly of institutions, social relations, and territorial coverage (McCann, 2016). For the context of low to middle income nations in Asia, Africa, and Latin America, a local government’s competency, accountability, and effectiveness, in particular, are the key to success (Satterthwaite, 2001; McGranahan and Satterthwaite, 2003)

Studies on governance in the South have discussed the influence of institutional legacies of (former) authoritarian regimes, which act as structuring forces for the management of urban and metropolitan regions. Under new democratic regimes, innovation is often found at the sub-national level and in metropolitan governance (see

among others Firman, 2010; Guarneros-Meza, 2009; Souza, 2005; Laquian, 2005; Porio, 2012; Vogel, et al. 2010). The Asian region represents some specific contextual 
characteristics. Local autonomy in Asia, for example, is often characterized by political fragmentation (Laquian, 2005). Local elites and "political dynasties" are commonly dominant in local leadership (Laquian, 2005; see also Porio, 2012). This paper discusses that within such influence of institutional legacies and political fragmentation, acknowledging that stakeholders are neither fully rational nor strategic in pursuing their goals within public sector networks is important. In steering the governance process, stakeholders may be driven by a strong local ego, as well as logic of appropriateness. Subsequently, any analysis of stakeholders' capacity should be expressed through the institutions and the social relations among actors involved.

This article views governance from a sociological institutionalist perspective, in which institutions consist of rights, systems of rules and roles, and decision-making procedures (Rothstein, 1996). The approach focuses on how and to what extent institutions influence individuals, organizations, or states to act in the social context where they are situated (DiMaggio and Powell, 1991, p. 11). Informality and power relations among groups are important (Senol, 2013). Institutions are not necessarily the product of conscious design. Therefore, institutions can be found everywhere in everyday life, emerge and transform through the building of relationships among actors, not merely conventions, but can become a rule like that of status in social thought and action. Institutions also represent collective outcomes, which are not the simple sum of individual interests (DiMaggio and Powell, 1991, pp. 7-11). Therefore, many institutional forms and procedures are adopted not because they are most efficient but because they are the cultural practices of stakeholders (Hall and Taylor, 1996). 
The governance of cities in a newly decentralized system is influenced by a wide range of interdependent relations between stakeholders. The stakeholders are situated in a rapidly changing institutional environment, and are likely to have diverse cultural backgrounds, resulting in disparate frames of thinking. Because of these differences, the cognitive processes in which stakeholders are involved in building and agreeing upon a shared meaning are essential for achieving collective action.

To examine governance in such changing institutional environment, this paper adopts a conceptual framework of institutional capacity (Healey, 2005). Institutional capacity is defined as the capacity of networks as a whole, created beyond what the individual actors possess prior to collaboration (Healey, 2005; Innes, et al. 1994, p. 47). The emphasis of this concept has been on the capacity to achieve shared understanding. More recently, the focus is on the capacity to boost innovation and pursue new policy agendas, particularly in public institutions (Agger and Sorensen, 2016).

The concept of institutional capacity may be operationalized through three variables: knowledge capital, relational capital, and mobilization capacity. Knowledge capital refers to knowledge exchange among diverse stakeholders, the learning process through the whole of stakeholder interactions (De Magelhaes et al. 2002, p. 54). Relational capital emerges through interactions during and around certain events. The nature, reach, and quality of relational networks brought by stakeholders to and generated in the collaborative process create relational capital (De Magelhaes et al. 2002, p. 54). Mobilization capacity involves the process of selection and identification of issues, range of mobilization techniques, consensus-building practices, and character and role of key agents (Khakee, 2002). Mobilization capacity emerges through the coupling of knowledge 
and relational capital, which enable the actors to utilize opportunities around them to finally endorse certain public policies (Healey, 2005).

The transformation of institutional capacity takes place at three different levels of governance: episodes, governance processes, and governance culture (Gonzales and Healey, 2005). At the level of episodes, the world view of people of varied positions interact, they express different ideas, discuss alternatives of strategies, and finally they make "decisions". Governance innovation here refers to, for example, ideas about possible roles and the societal position of water resources. People learn the practices and values embedded in established governance processes. Innovations at the episodes go into the deeper structures of the governance processes, and imply the emergence or renewal of institutional forms, for example when local funding of water infrastructures is involved. A transformation of culture to achieve collaboration is achieved by exploring the dominant assumptions, values, and practices of governance process. Culture refers to the ways of thinking and acting that are considered normal and routine, for example in established centralist regimes of water distribution. Innovations diffused through the governance processes must be able to challenge dominant governance practices and values to change governance culture, and create new institutional capacity (Gonzales and Healey, 2005).

\section{Water resources cooperation between Cirebon City and Kuningan District: Three Episodes}

Municipal cities in Indonesia are commonly located at the center of one or several districts. They have become a small core in a wider regional network. Beforehand, as Indonesia applied growth poles policy in the 1960s and 1970s (Hinderink and Titus, 1998), 
municipal cities became a focus of regional development policy for the central government. These were intended to be the center for the trickle-down development of their surrounding regions.

Currently, Indonesian decentralization policies have created a new setting for regional development and situated local-government collaboration efforts. Indonesia drastically transformed its centralized government into a decentralized one (e.g., Holzhacker et al, 2015). The provinces, municipalities, and districts have all become autonomous regions. The provincial governments were granted a dual status as autonomous regions and as representatives of the central government in the regions. The dual status has led to confusion because the provincial governments have a hierarchical status as well as an autonomous status.

Following further revisions, authorities and responsibilities among centralprovincial-local government are shared. There are thirty-one government tasks shared or distributed among all tiers of government. Obligatory tasks are those relating to basic service provision, while optional tasks relate to core competences of a region. For natural resources like water the provincial authority would take responsibility for issues of distributing state funding, while regencies and municipalities take on more applied tasks related to the use of natural resources and licensing.

Fiscal arrangements emphasize a revenue-sharing system between central and regional governments called the balancing fund (dana perimbangan). The balancing fund becomes part of local revenue as an addition to local income.

Following decentralization implementation, local leaders have been disposed to "local egoism" (Firman, 2010), thereby emphasizing their personal position to govern their 
territory and inherent resources. In such context, municipal cities tend to not only be smaller in size compared to their surrounding districts, but also minor in terms of bargaining power with them. The absence of natural resources in the city makes it imperative for the city to increase its capacity for collaborating with surrounding regions to deal with urbanization, both in managing the urban development process as well as providing urban services. A large proportion of natural resources is located in other regions outside the municipal cities - resources which the city requires for coping with increased urbanization and greater demand for services. Therefore, the challenges of the urbanization and decentralization require material capital and more importantly capacity to collaborate with surrounding regions. This collaboration effort should be pursued within the 'euphoria' of decentralization (Firman, 2003).

The development of institutional capital among the actors in shared fresh water resources between Cirebon City and Kuningan District can be viewed in terms of episodes. Three episodes were selected, based on their influence on the governance of fresh water resources for Cirebon City and Kuningan District.

The first episode is the central government's approach to sustainable water resources. Since the new decentralization policies, considerable changes regarding water resources management have taken place in Indonesia, especially in the area of sustainable management of water resources. Socio-economic considerations have been important as the Indonesian government enacts Government Regulation No. 77/2001, which stated that water is "an economic good with a social function". The idea is that if water is perceived as a public good, this would foster the perception that water is an abundant resource that can be consumed plentifully without any charge (p. 60). A result of long and careful 
consideration, Water Law No 7/2004 stipulates the necessity of accumulating knowledge about water resources management at the national level.

However, objections to this law have been raised. Judicial reviews have been submitted to the constitutional court regarding this law (Mahkamah Konstitusi, 2005). The objections are mainly due to the private sector's role in the system of provision of drinking water and in water resources management. After three judicial reviews (2003, 2013, and 2015), eventually, this Water Law was abandoned in 2015. However, the whole process of making this Law did generate some comprehensive thinking and efforts of central government to initiate innovative institutions to achieve sustainable water resources in Indonesia.

The Ministry of Public Works and Housing drew up Indonesia's comprehensive river basin management plan. This plan was followed by creating a range of centrally regulated institutions for implementation. The new institutions include Balai Besar Wilayah Sungai (BBWS)/ the institution to manage the river basin region, Dewan Sumber Daya Air (DSA)/the Council of Water Resources, and Tim Koordinasi Pengelolaan Sumber Daya Air (TKPSDA)/the Water Resources Management Coordinating Team. Despite these institutional innovations, however, from the interviews it is understood that the main issue from establishing them is that they offer limited opportunity to create stronger ties with local auhorities.

The second episode is piped water development in Cirebon City. Capital investment in Cirebon City for clean water services started when the Dutch government built a potable water supply system for Cirebon City in 1937. The main water resource remains the same: the spring water located in the Paniis and Singkup villages, Kuningan 
District. The flow to the city initially was 100 liters/second. Currently, it has increased to nearly 1000 liters/second.

A 1972 Master Plan for the City Clean Water System implied cooperation between the Ministry of Public Works and Nihon Suido Consultants of Japan. The process continued with assistance from the central government through a well-established program called CUDP (Cirebon Urban Development Program). This assistance were carried out for Cirebon City, given its national role as a 'main urban area' at that time, because of which the city was considered to have an increased need of piped water supply (CUDP Report, 1992).

Therefore, the main investment of capital from the central government, with the city mainly as the recipient, has gone towards efforts to improve the technical capacity in the exploitation of the current water source. A long history of good relations with the central government has made it that the city tends to communicate directly with the central government.

Long before Indonesia's decentralization policy in 2001, Cirebon City has had wellestablished informal communication with Kuningan District. However, communication between the city and district did not involve effective governance relations, but rather involved the city giving some money to the district as a gesture of gratitude for the use of their water resources. All the administrative and technical elements of the cooperation were arranged by the national and provincial governments.

The interviews confirmed that there has been no significant research into other options for clean water supply for the city. The lack of knowledge and financial capital for alternative water sources or water supply technologies has made the city dependent on 
Kuningan District for fresh water. This dependency will increasingly make an impact on the city in the face of changing local and regional networks and power relations as a result of decentralization policies and increased regional autonomy.

The third episode covers efforts to utilizing local potential by Kuningan District. Under new decentralization, Kuningan District has demonstrated an enthusiasm for innovative ideas and maximizing local potential. The newly elected Regent/Bupati of Kuningan has been a key person mobilizing a spirit of innovation. A new image of Kuningan as a district of conservation was created. The Bupati was the main initiator of the change in the function of Ciremai Mountain forest from production to conservation forest. The idea was supported and approved by the local parliament and the Ministry of Forestry within less than three months. The forest was converted to a conservation forest by a Decree of the Minister of Forestry in October 2004. This implies that the water resources located in Paniis and Singkup villages, would be under the authority of the Ministry of Forestry, with TNGC (Mount Ciremai National Park) office as the institution taking care of the area. The short time the process took and the speed with which an agreement was reached is evidence of strong mobilization capacity of a leader at the local level, and of good relational capital built with the central government by a local government, in this case by their leader/the Bupati.

The episode of Kuningan District indicates that the innovative ideas succeeded because of the strong mobilization capacity of the Regent/Bupati. The whole process and changes discussed above also show the increasing importance of Kuningan District in regional networks as they maximize their local potential under Indonesia's new 
decentralization. The dynamic changes occurring in Kuningan District strongly influences relations arising from cooperation efforts between the city and the district.

The three episodes indicate that under decentralization, ongoing regulations open up opportunities for local innovation. Demand for water combined with attitudes among local leader of regional attachment and local potential, have triggered the District to initiate cooperation with the City.

\section{Governance Process: The Interaction of Cirebon City and Kuningan District}

This section emphasizes the "governance process" level of institutional relations. The analysis focuses on the period between 2004 and 2008, when the collaboration was initiated, when the conflict started and escalated, and when it was "considered resolved". It is analyzed whether the Cirebon City-Kuningan District cooperation for fresh water resources is able to increase the institutional capacity of the networks of this cooperation as a whole.

\section{Assessment of potential coupling of knowledge and relational capital building}

An MoU for sharing water resources was signed on 17 December 2004 by the Mayor of Cirebon City and the Bupati of Kuningan District. The main point of the MoU was that Cirebon City agreed to contribute to conservation funding for the water catchment area in the Kuningan District. The Kuningan District was then responsible for conservation in the water catchment area and for installing a water meter at the horizontal storage well's main pipe that distributes water to the city. 
Several data sources reveal that the two parties had at least five meetings beforehand, from August to September 2004, but that no agreement was reached. The main reason for the deadlock was the difference between the amount of funding asked by Kuningan District (2.2 billion rupiah per year) and the amount the city considered affordable (407 million rupiah per year).

The interviews revealed that even though the agreement was eventually signed, the city, in particular PDAM of Cirebon City (Local Water Supply Agency), did not completely agree with the decision. The city signed the MoU to mainly maintain relations with Kuningan District. Shortly after that, at the end of December 2004, Cirebon City began gathering support, mainly through the Mayor, to change the terms of agreement. Support was mainly sought from the provincial government and other actors in the higher levels of government. They sought to build relations through a formal approach during 2004-2008, including many actors except Kuningan District itself, to move towards what they considered to be “following the right regulations".

The Mayor sent a letter to the governor of West Java as early as the end of December 2004. This was followed by many letters and meetings throughout the whole process arranged by The Regional Secretariat of West Java and by Regional Government Coordination and Development Body/BKPP during 2006 to 2007. All these meetings were responses to the letters from the Mayor. The city asked for re-negotiation of the amount of conservation funding. The city questioned the legal basis of cooperation and compensation asked by the Kuningan District after TNGC office has been established in December 2006. In the last meeting on November 1, 2007, all of the stakeholders in the conflict were invited: Kuningan District, Cirebon City, TNGC, BKPP, and Regional Secretariat officials. 
Analyses of the minutes of meetings show that there were several responses, and arguments that can be placed in two categories: responses opposed and in support of the cooperation.

The arguments and responses against the cooperation were as follows. An important argument on regulations was that the utilization of water resources should be managed comprehensively by the central government. Another issue was that no article in the Water Law mentions a compensation fee akin to the current practice between the city and Kuningan District. Compensation should be given for conservation activities, and not in terms of money. The arguments in support of the cooperation were Kuningan District has merely tried to find continuous funding to conserve the water catchment area to guarantee continuous water resources for the city and any other regions. The MoU has already been signed. Consequently, those who signed it should abide by the agreement reached.

In the end, the meetings were concluded with a report-letter from BKPP to the governor of West Java Province. The main points of the report seem to support the current form of cooperation between Cirebon City and Kuningan District. The governor provides the city financial aid to pay the conservation funding to Kuningan District for two years, 2006 and 2007. Following this, PDAM Cirebon City would have to pay the conservation funds to Kuningan District from its own income. Although some points against the current cooperation were included in the conclusions, they seemed to be included mainly to support the argument in its favor. The role of top-level government officials may have been quite influential for such an outcome. At any rate, it appears that new and common understandings of the problems have not yet emerged. From this analysis of the interaction process, it seems that several main issues formed a bottleneck. 
At the time of the dispute, a new Water Law had just been passed, and the Regional River Basin Management Plan had not yet been completed. For this reason, the institutions formed by Central Government such as BBWS, TKPSDA, and TNGC, had no part in the city’s efforts in building relations.

\section{Mobilization capital of Kuningan District and the city's communities}

After the dispute was considered resolved, the problem remained unresolved. The city`s dissatisfaction was evident in the delay of payment of conservation funding to Kuningan District, so that PDAM Kuningan District sent a letter to remind the city that their contribution was due.

In the end, Kuningan District decided to take the lead and mobilize its “opportunities” in the situation: the location of the water resources in the Kuningan District administrative region; the already problematic relations between the two regions; the existing MoU; and the supportive position of the provincial government (Interviews in 2012). At the beginning of November 2008, Kuningan District shut the gate valve allocating and measuring water from Paniis spring to the city. The decision to shut the valve was made to reduce the debit flow to the city and to send a strong message of warning and about the position of the district in relation to the city (Interviews in 2012).

As a result, people in Cirebon City, who had already been very dissatisfied with the piped water services for several months, demonstrated at Cirebon City Hall. The community was of the opinion that the amount of water piped to households was very limited and that the flow trickled the last several months. Running water was not sufficient for bathing and cooking. A meeting between community members, the head of the regional 
secretariat and the Mayor of Cirebon City was unsuccessful, because the officials could not promise when the water debit would be normal again.

After several days of reduced water supply, an emergency meeting was held between the Mayor of Cirebon City and the acting Bupati of Kuningan District (the Bupati who initiated the conservation fund was the incumbent at the time when the dispute escalated. He was preparing to run again in the election for next period). Finally, the Mayor signed an agreement letter. The letter was clearly stating that the city would pay its contribution for conservation, half in 2008 and the rest in April 2009. The gate valve was opened to its normal flow.

Not long after this crisis, at the end of December 2008, the Mayor appointed a new director of PDAM. The main task of this new director was to restore governance relations between the city and Kuningan District, and normalize the water crisis that had been ongoing for several years. Cirebon City and Kuningan District have since moved on to new episodes of governance relations. Instead of resorting to power and formal arrangements, the newly elected director of PDAM Cirebon City decided to adapt a more informal approach: practicing humility, maintaining good intentions, and recognizing that the city is the dependent party in the relationship with Kuningan. One of the officials interviewed admitted this: "I don't see an equal relation between Cirebon City and Kuningan District" (Interviews in 2012)

In the new approach, the city met with Kuningan District's key stakeholders: the regional secretariat, the Bupati, PDAM, and the local agency for water resources . The city also made informal visits, attending the anniversary celebration party of Kuningan District, for example. The city also addressed the needs of the villages of Singkup and Paniis, such 
as clean water and electricity. The main principle emerging from the long dispute is "provide the conservation funding asked by Kuningan District, and the more detailed regulatory issues will follow later”. The interest of the citizens is the most important issue for the city. Cirebon City's drastic change in attitude was welcomed by all the stakeholders in Kuningan District.

The governance process shows that throughout the open and sharp disagreements, two crucial insights emerged. First an awareness among local government that their own local government neighbors are key partners. And, second, the understanding that an informal approach is influential to dealing with local ego.

\section{Governance Culture: Assessment of the Potential Transformation of Culture}

In the period under study, Cirebon City was situated within governance arenas in which all of the stakeholders brought different knowledge, storylines, and their own relational capital. Relevant regulations were then still being developed. Two phases can be identified: the first phase during the dispute, and the second phase after the dispute was considered resolved.

Even though the city realized the imbalance of their position due to scarcity of resources at the beginning of the process, they strongly believed that they were on an equal footing with the other actors involved in the broader networks related to the cooperation for shared water resources. The city was confident that the new regulations and a formal approach would create sufficiently dense networks to back up their position in renegotiating the conservation funding and questioning the legal basis of the current cooperation. However, in this first phase of the cooperation, the Cirebon City government 
tended to ignore the most important actor in the networks under the Indonesia's new decentralization policies: Kuningan District itself. Meanwhile, the actors from Kuningan District came to the governance arena with strong mobilization capital held by their leader who emphasized the importance of utilizing local potential, including water resources. The mobilization capacity of the Bupati changed Kuningan District into an emerging administrative region in its own right, rather than just a peripheral region of the city. The provincial government actors responded to this dispute in different ways. The middle-level officials argued that all the stakeholders should be aware of how the new regulations affected the collaboration. This is similar to part of the argument put forward by Cirebon City that the current cooperation would have to be adjusted in the near future, because it was not compatible with the new regulations. However, legislation is still ongoing. The provincial government leaders involved in the dispute suggested resolving the situation based on "the logic of appropriateness" which they consider the most suitable approach. It is appropriate that the conservation of water resources is the primary responsibility of the upstream region (Kuningan District). It is also appropriate for Cirebon City to pay a conservation fee because they utilize the water and benefit financially from it. It is appropriate that Kuningan District receives the conservation fee because they are the upstream region. The current cooperation should be continued.

The influence of culture, specifically traditional culture ${ }^{\mathrm{i}}$ and traditional cultural leadership in a bureaucratic system proved to be essential in building cooperation between regions in Indonesia (Hudalah, Firman, Woltjer, 2014). It appears, however, that the Cirebon-Kuningan case at both sides lacked traditional cultural leaders who could influence the local actors. Moreover, there is no indication that daily routine and traditional 
culture bound the actors together in their attempts to unite all of the actors in the governance process. In this particular circumstance, the traditional cultural leader was absent; also lacking were the daily routines of a common culture of cooperation efforts involving public institutions. A legacy of the previous government regime is the commodification of traditional culture in public institutions. The following discussion investigates the claim that this type of culture has the potential to influence the ways of thinking that shape the actions, approaches, and decisions in the cooperation for fresh water.

The political culture of Java Island is strongly characterized by traditional Javanese culture. Many scholars claim that in the authoritarian era of the New Order regime, the Javanese aristocratic culture was rigorously adopted as the general Indonesian nationalpolitical culture (Pemberton, 1994; Liddle, 1996; Pye, 1985; Antlov and Hemell, 2005). Jones (2013, p. 3) asserts that this culture was adopted to strengthen the authoritative power of the New Order regime by avoiding conflict and emphasizing the importance of hierarchical relationships. The political institutionalization of this culture had already taken place several decades ago. Therefore, the influence of such institutionalization is to a certain extent relevant in the era of Indonesia's new decentralization (see Jones 2013), particularly through the public institutions (Irawanto, Ramsey, and Ryan, 2011).

Liddle (1996, p. 65) argued that one of the cultures utilized by the previous regime was that of the Javanese political elite, which was among the most status-conscious and hierarchy-minded in the world. Bureaucrats distinguish sharply between themselves and the common people (rakyat) (Liddle, 1996, p. 65). Consequently, a strong culture of patrimonialism in state-society relations has emerged within Indonesian political culture (Liddle, 1996, p. 64). Jones (2013, p. 5) explained that patrimonialism in Indonesia refers 
to vertically structured patron-client relationships, in which resources are channeled to “clients", with different patron-client cartels competing for rewards dispensed by the ruler. This culture creates strong relationships characterized by feelings of obligation between superior and inferior.

This type of political culture institutionalized in public institutions is a leading factor in the cooperation. The process shows that an unequal relationship, like that of a paternalistic culture, exists in the cooperation. Liddle (1996) has argued that in the Soeharto era, Indonesian authoritarianism had particular characteristics, with the appearance of the so-called New Order Pyramid: A dominant presidency, politically active armed forces, and a decision making process centered in the bureaucracy. Patterns of state-society relations combined cooptation and responsiveness with repression. Participation essentially represented a political resource utilized by groups outside the government to gain hearing for their demands and by Soeharto to increase the legitimacy of his government (p.8). New order stability was a product of outside state participation (p. 17)..

The episodes and governance process of our case shows that certain aspects of the New Order Pyramid remained. Interlocal government cooperation for the management of natural resources typically features efforts to share resources. It also usually features situations where one of the local authorities is richer in natural endowments. The mechanism would involve a local leader with the power of mobilization leading the cooperation. Mobilization is strengthened by wide-open opportunities of performing discretionary decision-making, and controlling natural resource endowments. Discretionary decision-making is conducted on behalf of community interests and the region under their authority. Therefore, discretionary decision-making processes by the 
leader are supported by processes of acting on behalf of community interests and utilizing the availability of natural resources. Both aspects symbolize the two ends of a pyramid, supporting the local leader's mobilization. Under decentralizing Indonesia, the position of communities have become stronger, as they are the constituents of an elected political leader. In addition, the Regent has a strong sense of belonging to Kuningan, where he was born and been raised. He persistently created a new identity for Kuningan District as a conservation district and "an important region, not only a rural area" (Interview with Bupati of Kuningan District in 2012).

For government officials, especially top leaders such as the Regent or Mayor, and also middle-level officials, sometimes their individual pride, sense of identity, and emotions were caught up in their role as the head of the region or officials of public institutions. There is a kind of association between a role in a public institution or in the public sphere, and the identity of an individual. This phenomenon may be apparent a leaders persistently use the pronoun "we" to refer to the region that he leads. Refusal to follow the policy of the region can therefore be taken as an offense against the individual as well. Conflict in a region becomes complicated when the role of the leader of the region is mixed up with ego and pride. Cirebon City, at the end of the dispute, realized the "actual" circumstances under decentralization and regional autonomy, and decided to accept its status as the inferior in this network. The city positioned itself as the client receiving resources from its patron.

Liddle (1996, p. 81) argues that another explicit result of applying this aristocratic culture to public institutions is the notion that the king can do no wrong, in which a government's policy-making process is dependent on the discretion of the 
king/leader/ruler, instead of being structured by law or mandatory processes (Liddle 1996, p. 81). In the case of this cooperation, the influence of the top level of provincial government lies in the discretion of the leader. Discretion was strongly influenced by the logic of what is considered appropriate. The logic of appropriateness underlying decisions may have also been influenced by the culture of tolerance and the avoidance of dispute, which should be practiced by a leader. The good intentions of a leader will guide him/her in resolving disputes according to social logic. The downstream region was seen as the region that needs the water, utilizes the water, and receives material and financial benefit from the water. The upstream region was seen as the region most affected by the utilization of the water, and so it is the most appropriate actor to carry out a conservation program for the water catchment areas. It was therefore considered logically appropriate for the downstream region to contribute directly to the upstream region.

The assessment of governance culture shows that patron-client relations remain attached to institutional innovation efforts. However, the fact that local leaders and local government officials involved such initiatives are directly acting on behalf of their community may represents a promising sign of new insitutitonal capacity in decentralized Indonesia.

\section{Discussion and Conclusions}

The paper reveals several requirements for water resource coordination in an urbanizing municipal city in Indonesia. The case also shows amplified dependencies of the municipal city with its surrounding district. The social processes and governance arrangements in place are strongly based on decentralized logic and largely extemporary at the regional level. 
Governance processes for upstream-downstream coordination also show limited integration between water and the broader range of related land-use and urbanization activities. Although an urban region has been developing in the case, with a pressing need for coordination, capacities for regional governance remain disjointed and politically discrete. A reliance on local histories of agreement-making and traditional patron-client relationships emerge as particularly strong.

We suggest that the cooperation efforts discussed in this paper are an indication of the institutionalization of a particular patrimonial culture into political institutions. This culture is well-established historically, and fosters strong relationships characterized by a spirit of obligation between superior and inferior. The district functions as the patron channeling resources to the municipal city as its client. The city, which recognized that networks had changed, decided in the end of the dispute to accept its status and positioned itself as a client who receives resources from its patron. However, despite the patron-client relations, the case has also shown that new institutional capacity is emerging for the practices of inter local government cooperation.

Reflecting three stages of institutional capacity's transformation to the 'pyramid of New-Order', this case shows that a new 'pyramid' of New-Order culture appears in the context of the new decentralizing Indonesia (illustrated in Figure 2). Currently, the local leaders (both city and district) have mobilization power supported by wide-open opportunities of performing discretionary decision-making.. Local leaders are positioned at the peak of the triangle for institutional capacity. The other two angles of the pyramid are community interests and natural endowments. Under new Indonesian decentralism, one of the most significant transformations is that the position of the community becomes 
stronger, as they are the constituents of an elected political leader. Thi is indicated by the concern to community's need become the basis to settle down the conflict. Simultaneously, natural resources develop into a basis of shared power to initiate inter local government cooperation. Natural resources like water essentially are used as a natural capital base to negotiating regional coordination.

Figure 2. Triangle of Local Capacities for Water Governance

The current context is that community constituents and natural resources both support governance processes and institutional innovation at the local level. However, within such context, there is a risk of coercion through patrimonial leadership, resembling a traditional culture of authoritarian rule. Natural resources in particular become an increasingly forceful ingredient of interlocal coordination and negotiation -particularly when it involves an increasingly restricted resource such as water. It seems crucial to transform community capacities in terms of knowledge, and transform the understanding of natural resources from a position as static capital into a role as shared natural capital. Shared natural capital then functions as flows of capital leveraging inter-local cooperative forms of water governance.

To conclude, the governance of small cities shows that a dramatic change is possible to happen, in which initiative and innovation for regional networks comes from 
the local level, even though for decades local government was just a passive recipient of central government policy. This change involves a significant shift from formal approaches to a discretionary approach and appropriateness in the decision-making process, involving inter-local government cooperation. The actions taken by local governments indicate a strong emphasis on the mobilization capacity for issues like water, and a general focus on legitimacy and acceptance. The case also suggests that regional governance between local governments has an extemporary spirit and is guided considerably by inter-local rivalry over natural capital.

For small cities in the global South that undergo decentralization, and are experiencing similar patterns of newly-formed of regional networks involving issues of urban growth and related environmental resources, emphasizing networking capacity and strengthening the legitimacy of regional coordination would be beneficial. Further research into understanding decentralized political control over water resources is also required.

\section{Funding}

This research received no specific grant from any funding agency in the public, commercial, or not-for-profit sectors.

\section{References}

Agger, A., and Sorensen, E. (2016). Managing collaborative innovation in public bureaucracies. Planning Theory, 1-21. https://doi.org/10.1177/1473095216672500

Antlöv, H. (2003). Bulletin of Indonesian Economic Studies village government and rural development in Indonesia: the new democratic framework. Bulletin of Indonesian Economic Studies, 39(2), 193-214. https://doi.org/10.1080/00074910302013 
Antlov, H., and Hellman, J. (2005). Introduction: Images of Java in academic discourses. In H. Antlov and J. Hellman (Eds.), The Java that never was (pp. 1-20). Lit Verlag: Munster.

Cohen, B. (2006). Urbanization in developing countries: Current trends, future projections, and key challenges for sustainability. Technology in Society, 28(1-2), 63-80. https://doi.org/10.1016/j.techsoc.2005.10.005

Cirebon Urban Development Project II (1991) Dirjen Cipta Karya Depatemen PU: Jakarta.

De Magelhaes, C., Healey, P., and Madanipour, A. (2002). Assessing Institutional Capacity for City Center Regeneration: New castle’s Grainger town. In C. Goran, P.Healey and A. Madanipour (Eds.), Urban governance, institutional capacity, and social milieu (pp. 45-61). Ashgate Publishing: Burlington.

DiMaggio, P.J.,and Powell, W.W. (1991). Introduction. W.W. Powell and P.J. DiMaggio (Eds.), The new institutionalism in organizational analysis (pp. 7-11). University of Chicago Press: Chicago.

Fahmi, Z. F., Hudalah, D., Rahayu, P., and Woltjer, J. (2014). Extended urbanization in small and medium-sized cities: The case of Cirebon, Indonesia. Habitat International, 42, 1-10

Firman, T. (2003). Potential impacts of Indonesia's fiscal decentralisation reform on urban and regional development: Towards a new pattern of spatial disparity. Space and Polity, 7(3), 247-271. https://doi.org/10.1080/1356257032000169712

Firman, T. (2010). Multi local-government under Indonesia’s decentralization reform: The case of Kartamantul (The Greater Yogyakarta). Habitat International, 34(4), 400-405. https://doi.org/10.1016/j.habitatint.2009.11.005 
Gonzales and Healey (2005) A sociological instittionalist approach to innovation in urban governance. (2005). Urban Studies, 42(11), 2055-2069.

https://doi.org/10.1080/00420980500279778 The

Gore, C. D., and Gopakumar, G. (2015). Infrastructure and metropolitan reorganization: an exploration of the relationship in Africa and India. Journal of Urban Affairs, 37(5), 548-567. https://doi.org/10.1111/juaf.12180

Guarneros-Meza, V. (2009). Mexican urban governance: How old and new institutions coexist and interact. International Journal of Urban and Regional Research. https://doi.org/10.1111/j.1468-2427.2009.00864.x

Hall, P. A., and Taylor, R.C.R. (1996). Political science and three institutionalism. Political Studies. XLIV: 936-957.

Han, S. S. (2010). Urban expansion in contemporary China: What can we learn from a small town? Land Use Policy, 27(3), 780-787. https://doi.org/10.1016/j.landusepol.2009.10.010

Hawkins, C. V., Hu, Q., and Feiock, R. C. (2016). Self-Organizing Governance of Local Economic Development: Informal Policy Networks and Regional Institutions. Journal of Urban Affairs, 38(5), 643-660. https://doi.org/10.1111/juaf.12280

Healey, P. (2005). Collaborative planning: Shaping places in fragmented societies (2nd ed.). Palgrave MacMillan: New York.

Hinderink, J., and Titus, M. (1998). Paradigms of Regional development and the Role of Small Centers. In M. Titus and J. Hinderink (Eds.), Town and hinterland in developing countries (pp.5-18). Thela-Thesis: Amsterdam.

Holzhacker, R., Wittek, R., Woltjer, J. (eds.) (2015) Decentralization and Governance in Indonesia. New York: Springer. 
Hoornbeek, J., Beechey, T., and Pascarella, T. (2016). Fostering local government collaboration: An empirical analysis of case studies in Ohio. Journal of Urban Affairs, 38(2), 252-279. https://doi.org/10.1111/juaf.12204

Hudalah, D., Firman, T., and Woltjer, J. (2014). Cultural Cooperation, Institution Building and Metropolitan Governance in Decentralizing Indonesia. International Journal of Urban and Regional Research. https://doi.org/10.1111/1468-2427.12096

Innes, J., Gruber, J., Neuman, M., Thompson, J. (1994). Coordinating growth and environmental management through consensus building. Working paper. California Policy Research Center, Berkeley, USA.

Irawanto, D. W., Ramsey, P. L., and Ryan, J. C. (2011). Challenge of leading in Javanese culture. Asian Ethnicity, 12(2), 125-139. https://doi.org/10.1080/14631369.2011.571829

Jones, T. (2013). Culture, power, and authoritarianism in the Indonesian state: Cultural policy across the twentieth century to the reform era. Koninklijke, Brill NV: Leiden.

Khakee, A. (2010). Assessing Institutional Capital Building in a Local Agenda 21 Process in Goteborg. Planning Theory and Practice, 3(1), 53-68. https://doi.org/10.1080/14649350220117807

Laquian, A. A. (2005). Metropolitan governance reform in Asia. Public Administration and Development, 25(4), 307-315. https://doi.org/10.1002/pad.384

Kim, J. H., Keane, T. D., and Bernard, E. A. (2015). Fragmented local governance and water resource management outcomes. Journal of Environmental Management, 1-9. https://doi.org/10.1016/j.jenvman.2014.12.002

Klaufus, C. (2010). Watching the city grow: remittances and sprawl in intermediate Central American cities. Environment and Urbanization, 22(1), 125-137. https://doi.org/10.1177/0956247809359646 
Liddle, R. W. (1996). Leadership and culture in Indonesian politics. Asian Studies Association of Australia with Allen and Unwin: Sydney.

Liu, Y., Yin, G., and Ma, L. J. C. (2012). Local state and administrative urbanization in post-reform China: A case study of Hebi City, Henan Province. Cities, 29(2), 107117. https://doi.org/10.1016/j.cities.2011.08.003

Mahkamah Konstitusi. (2005). Air potensial menjadi sumber konflik. Berita Mahkamah Konstitusi, Retrieved from http://www.mahkamahkonstitusi.go.id/public/content/infoumum/majalahkonstitusi/p df/BOOK_BMK\%209.pdf

MacLeod, G. (2011). Urban Politics Reconsidered. Urban Studies, 48(12), pp.2629_ 2660. Available at: http://journals.sagepub.com/doi/10.1177/0042098011415715.

McCann, E. (2016). Governing urbanism: Urban governance studies 1.0, 2.0 and beyond. Urban Studies, 54(2), pp.312-326. Available at: http://journals.sagepub.com/doi/10.1177/0042098016670046.

Megdal, S., Eden, S., and Shamir, E. (2017). Water Governance, Stakeholder Engagement, and Sustainable Water Resources Management. Water, 9(190): 1-7. https://doi.org/10.3390/w9030190

Miles, M.B., and Huberman, M.(1994). An expanded hand book: Qualitative data analysis, Sage Publications: London.

Pemberton, J. (1994). On the subject of Java, Cornell University Press: New York.

Pye, L. W. (1985). Asian power and politics, Harvard University Press: Cambridge, Massachusetts, London.

Rothstein, B. (1996). Political Institutions: An overview. In R. E. Goodin and H. D Klingemann (Eds.), A new handbook of political science (pp. 133-166). Oxford University Press: Oxford. 
Satterthwaite, D. (2001). Environmetal governance : A comparative Analysis of nine cities, Journal of International Development, 13, 1009-1014. https://doi.org/10.1002/jid.824

Senol, F. (2013). Elected Neighbourhood Officers in a Turkish City (Izmir): Gendered Local Participation in Governance. Urban Studies, 50(5), pp.977-993. Available at: http://usj.sagepub.com/cgi/doi/10.1177/0042098012458004.

Tirtosudarmo, R. (2012). Urbanization without Development: The cases of Cirebon and Gresik on Java’s north coast. In T. Bunnell, D. Parthasarathy, E.C Thompson (Eds.), Cleavage, connection, and conflict in rural, urban, and contemporary Asia (pp. 99116). Springer: London.

United Nation. (2010). World Urbanization Prospects: The 2009 revision highlights. Retrieved from: http://esa.un.org/unpd/wup/Documents/WUP2009_Highlights_Final.pdf.

Sudarmo, S.P and Brasukra, G.S. (2009). The Missing Link The Province and Its Role in Indonesia's Decentralisation. UNDP Indonesia: Jakarta

Vogel, R. K., Savitch, H.V., Xu, J., Yeh, A. G. O., Wu, W., Sancton, A... Newman, P. (2010). Governing global city regions in China and the West, Progress in Planning, 73, 1-75. https://doi.org/10.1016/j.progress.2009.12.001

White, I. (2010). Water and the City: Risk, Resilience and Planning for a Sustainable Future. Routledge: London.

Wu, F. (2002). China’s Changing Urban Governance. Urban Studies, 39(7), pp.10711093. 
i Traditional culture refers to the values, traditions, and languages of the diverse ethnic groups in Indonesian society, such as Javanese, Sundanese, Acehnese, Bataks, Minangkabau, and so on. The national culture of Indonesia is considered a more modern culture. The national culture has been influenced by Western culture, socialized through the educational system, and deliberately promoted by the policy of the government of the Republic of Indonesia since independence (Liddle, 1996, pp. 63-106). The New Order regime utilized the national political culture and was an authoritarian regime (Jones, 2013). 